\title{
Рецензія на підручник "English for Third-year Students" за авторством В. В. Іванчука, С. В. Богун, Л. В. Князєвої, Н. О. Горькавої (Київ: Вид. центр КНЛУ, 2018)
}

Коли перед тобою лежить річний курс англійської мови в двох томах і кожен з них по 300400 сторінок, мимоволі з'являється неоднозначне почуття: з одного боку - славний здобуток, 3 іншого - як цю громаду здолати за нечисленні аудиторні години на тиждень. Спробуємо 3'ясувати, що запропонував колектив авторів унаслідок двох років роботи і чи нове видання вирішує проблеми, чи, можливо, додає нових. Огляд змісту, структури курсу і розуміння авторського бачення неминуче дадуть відповіді на ці запитання.

Завдання курсу. Основоположним документом у нашому контексті є "The Curriculum for English Language Development in Universities and Institutes”, в якому зазначено, що завдання третього курсу яке розглядається в динаміці переходить зі створення засад лексичної і граматичної правильності - головне завдання впродовж перших двох років навчання на вільність і плавність мовлення. Запроваджується блок тем, які належать до фахових галузей (мовознавство - поширення англійської мови у світі, кіно, педагогіка, соціологія, психологія, мистецтво, екологія, біологія); акцентується на розвитку окремих умінь з опорою на широкий спектр навчальних матеріалів попереднього рівня складності.

Тобто, підручник для третього курсу факультетів англійської мови має (1) грунтуватися на вже сформованих засадах граматики й базового вокабуляру за основними розмовними темами, (2) представляти численні автентичні й неадаптовані текстові, аудіо- і відеоматеріали 3 передбачених для вивчення галузей, (3) поставити завдання і запропонувати методику подальшого розвитку мовленнєвих умінь читання, вільності й плавності монологічного й діалогічного мовлення, вдосконалення умінь письма й аудіювання.

Структура підручника. Автори підручника пропонуть шість програмних тем. Кожна тема ділиться на чотири самостійних підрозділи, які пов'язані тематично, але розглядають різні аспекти теми, сфери чи галузі.

Підрозділ починається з уведення в тему й окреслення основних питань на матеріалі раніше вивченого. Тут же пропонується відеосюжет (існує також аудіоверсія) з відповідними завданнями й часто подальшим обговоренням. Усі тексти відеосюжетів зібрано в додатку розшифровок відеоряду в кінці кожного тому на випадок труднощів розуміння або бажання студента попрацювати над мовним наповненням додатково.

Підручник усуває труднощі граматичної будови наступного тексту у вигляді граматичного коментаря, а в кінці розділу зупиняється на цьому явищі докладніше у вигляді розширених тлумачень і граматичних вправ. У кінці кожного тому міститься граматичний довідник, в якому подається максимально повне освітлення граматичних явищ.

Текстові матеріали запозичено з сучасних джерел, таких як газета the Guardian, журнали the Times, New York Magazine, Vanity Fair, автентичних інтернетівських урядових сторінок, періодичних видань, блогів, художньої літератури й читацьких коментарів. 3 метою сприяння докладному виченню мовного матеріалу до кожного тексту додано численні примітки з фонетичною транскрипцією слова, перекладами українською мовою до ймовірно нових слів i слів, що зустрічались раніше, але ймовірно, що опрацьовувалися грунтовно. Додатково і за необхідності додається країнознавча й енциклопедична інформація до власних назв і передбачувано складних понять. У кінці кожного тому додається глосарій, де в алфавітному порядку зібрано всі лексичні одиниці, які могли б складати труднощі розуміння в читанні. Для акцентування уваги студентів “цікаві” мовні одиниці в текстах, включаючи ідеоматичні вислови, виділено жирним шрифтом. 
Активна лексика опрацьовується в три етапи: вправа 3 тлумачним словником; вправа в перекладі відповідних лексичних одиниць у різних контекстах рідною мовою і вправа в перекладі речень з означеною лексикою англійською мовою. Подібним чином опрацьовуються ідіоми й фразові дієслова. Також існують файли з ключами до основних вправ у перекладі англійською мовою (поза підручником і в обмеженому доступі).

Мовленнсві вправи, обговорення й рольові ігри грунтуються на вже засвоєному лексичному матеріалі й пропонуються в розвитку від керованих / жорстких вправ до вільних обговорень.

Завершує роботу над циклом написання есе, статей, звітів.

Посилання на джерела подаються у вигляді QR кодів і дають змогу миттєво переходити до початкових гіпертекстів, споріднених джерел і відеоматеріалів в online.

Висновки. Підручник безумовно має комунікативне спрямування і ставить за мету передусім підвищити рівень володіння студентами усним мовленням. Численні вправи на відтворення тексту на перших етапах й обговорення і рольові ігри надалі створюють умови для вдосконалення мовленнєвих умінь на третьому курсі.

Підручник практично вибудовує свій лексикон для всієї тематики курсу, залишаючи весь пласт нейтральної й “нефахової” лексики перших двох років навчання на “чорний день”. Мовленнєві вправи беззастережно вимагають вживання активної лексики, і через певний час викладач / студент отримує іншу якість мовлення.

3 подачею рясних приміток 3 фонетичною транскрипцією й українськими перекладами відразу вирішується п'ять важких завдань: (1) студенти більше не скаржаться на обсяги текстів для домашнього завдання, (2) неймовірно рідко звучить спотворена вимова маловідомих слів, (3) зникає необхідність пересвідчуватись у ретельності домашнього опрацювання текстів вже в аудиторії, (4) суттєво розширюється пасивний словниковий запас i, врешті, (5) за необхідності, чистий український переклад, за умов браку грунтовних українських словників, перестає бути викликом.

Водночас не слід боятися максималістського характеру підручника. Попри те, що автори ставлять амбітні цілі - пропонується переклад неймовірно великої кількості лексичних одиниць, жирним шрифтом виділяються численні слова й вирази в неадаптованих текстах - кількість активної лексики залишається помірним - близько 1000.

В історичній перспективі були часи, коли навчальний план передбачав набагато більше, ніж 6-8 годин (три-чотири пари) англійської мови на тиждень. Викладацький склад ще не залишив мрій, що таке благоденство ще, може, прийде. У всякому разі, цей підручник до цього готовий. Якнайкраще йому потрібно п’ять пар на тиждень. А тим часом і за умов сьогодення кожна кафедра може вирішувати, скільки брати підрозділів для аудиторної роботи, скільки давати на самостійне опрацювання, а скільки залишити поза увагою. Модульна побудова кожної теми забезпечує такий підхід без втрати якості самого процесу.

I на завершення, попри всі обсяги, це - “легкий” підручник. Автори намагались усунути все, що складало раніше марудну частину навчання - технічний пошук слів. У цьому підручнику все з примітками, пояснено й виділено, лексична одиниця щонайменше вживається вісім разів. Аудиторія гуде від обговорень і дискусій. Всі, які прагнуть, - дерзайте!

Рецензент

старший викладач кафедри фонетики і

практики англійської мови

Київського національного лінгвістичного університету

Д. П. Яремко 